\title{
IMPACT OF CULTURE TOWARDS DISASTER RISK REDUCTION
}

\author{
Udayangani KULATUNGA \\ School of the Built Environment, The University of Salford, Salford, M5 4WT, UK. \\ E-mail: U.Kulatunga@salford.ac.uk
}

Received 17 August 2010; accepted 30 October 2010

\begin{abstract}
Number of natural disasters has risen sharply worldwide making the risk of disasters a global concern. These disasters have created significant losses and damages to humans, economy and society. Despite the losses and damages created by disasters, some individuals and communities do not attach much significance to natural disasters. Risk perception towards a disaster not only depends on the danger it could create but also the behaviour of the communities and individuals that is governed by their culture. Within this context, this study examines the relationship between culture and disaster risk reduction (DRR). A comprehensive literature review is used for the study to evaluate culture, its components and to analyse a series of case studies related to disaster risk.

It was evident from the study that in some situations, culture has become a factor for the survival of the communities from disasters where as in some situations culture has acted as a barrier for effective DRR activities. The study suggests community based DRR activities as a mechanism to integrate with culture to effectively manage disaster risk.
\end{abstract}

KEYWORDS: Anthropologist; Culture; Components of culture; Disaster risk reduction; Livelihood patterns

\section{INTRODUCTION}

Disasters are defined as sudden events that bring disruption to a society with human, material, economic and environmental losses or impacts that exceed the ability of the affected community to cope up with by using their own resources (UN/ISDR, 2009). Considering the fact that disasters do not have to be always a sudden event but can develop over a time period EM-DAT (2009) defines disasters as a situation or an event that overwhelms the capacity of the affected community which seek national or international assistant. Implementation of appropriate disaster risk reduction (DRR) measures is an important element in disaster management. Lack of DRR measures could lead to significant loss and damage to human and materials and could hamper economic wealth of the society.

Over the past years, natural hazards have caused extensive losses and damages to human lives, physical facilities and socio-economic conditions of the affected communities. For example Indian Ocean Tsunami (2004), Hurricane Kathrina in New Orleans (2005), earthquake in Italy (2009) and floods in Pakistan (2010) have created losses and damages to disrupt essential functions and development goals of the economy and society. Further these natural disasters have increased stress and vulnerability of people and disempowered individuals and society hampering individuals and communities' development even in the long-run. However, the degree to which these so called natural hazards to be considered as 
"natural" is being questioned (Haigh and Amaratunga, 2010). Similar to the views of Haigh and Amaratunga (2010), Wisner et al. (2004) asset that natural hazard only cannot create extensive losses and damages, but poorly managed interactions between society and environment contribute to convert natural hazards into disasters. Vulnerability of community towards a disaster can be depend upon the factors related both physical and social elements of the community (McEntire et al, 2010) but do not need to totally depend on the natural hazard it self.

Therefore, it is argued that "natural disasters" are also created by humans by increasing the vulnerability of people towards extreme physical events by constructing unsafe buildings, poor urban planning, poverty and dense population. Therefore, considering natural hazards as events beyond human control is being challenged but the root causes of the disasters are evaluated to find effective solutions to minimise the losses and damages to humans, economy and social activities.

Despite the danger and losses from hazards, sometimes people do not attach much significance for them. For example, why do some communities live in the slopes of active volcanoes? According to the views of anthropologists (who study about humankind especially human culture and human development), cultural factors influence behaviour of people when facing to a hazard (Oliver-Smith, 1996). They argue that during a hazardous situation, people not only consider the danger that they could encounter, but give a priority for factors like social values, religious believes, traditions, and attachment to a location.

Accordingly, this study examines the impact of culture towards DRR through a comprehensive literature review. The study first evaluates the definitions and elements of culture. This is followed with an analysis of several case studies related to disaster risk along with cultural aspects to ascertain links between culture and DRR. Finally, the study leads to a discussion on highlighting the areas that we need to consider for effective integration of culture towards DRR.

\section{CULTURE}

\subsection{What is culture?}

The importance of culture towards disasters was particularly highlighted during the Indian Ocean Tsunami. When the Tsunami hit the coast lines of the south Asian countries in the year 2004, some communities with indigenous knowledge regarding Tsunami were successfully survived where as migrants and tourists who did not had local knowledge were hugely affected (Arunotai, 2008). Survival of some indigenous communities as oppose to migrants and tourists were mainly based on the presence of "cultural" knowledge different people had on the Tsunami. People view culture in different ways and some argue that it is complex and difficult to define. For some, culture is simply the way of life that expresses certain meanings and values of people (Williams, 1961). Baligh (1994) extends Williams's (1961) definition and sees culture as the ultimate way of doing things or a way of finding ways of doing things. Anthropologists view world as a "cultural mosaic" of traditional culture and inherited values (Nanda and Warms, 2007). The famous anthropologist Edward Taylor claims that culture as the "complex whole which includes knowledge, belief, art, moral, law, custom and any other capabilities and habits acquired by man as a member of society" (Taylor, 1924). Similarly, Swidler (1986) sees culture as a tool kit comprising of symbols, stories, rituals, and world views which people may used in different situations. These elements within culture are passed down from one generation to another and provide guidance for individuals to survive in the society (Hall et al., 2003). 
Some of the definitions for culture encompass a "group element". Schein (2004) defines culture as 'a pattern of shared basic assumptions (beliefs) that was learned by a group as it solved its problems of external adoption and internal integration, that has worked well enough to be considered valid". Since cultural aspects are considered valid and help groups for their survival, it is taught to new members as the correct way to perceive, think, and feel in relating to those problems (Schein, 2004). Similarly Rapoport (1987) sees culture is "about a group of people who have a set of values and beliefs which embody ideas, and are transmitted to members of the group through enculturation". Haviland (1993) describes culture as the common denominator that makes the actions of individuals attached to a group or not. Due to this strong link between "culture" and "group" they cannot exist without the other.

Having explored some of the definitions of culture, next section evaluates the components of culture.

\subsection{Components of culture}

Culture can be divided into two components as material and nonmaterial. Material culture consists of physical or tangible creations that members of society make, use or share where as nonmaterial culture consists of the abstracts and intangible human creations of society that influence people's behaviour (Ogburn, 1966 cited in Schaefer, 2009). At the most basic level, material culture is important for us to protect against the environment for example houses. Beyond this level, material culture can indicate your personality for example the clothes we wear (Kendall, 2010). Some other examples of material culture include crafts, historic buildings, locations (UNESCO, 2003; Throsby, 2001). Nonmaterial culture comprises of beliefs, values, language, rules of behaviour, family patterns, political systems, networks.
Kendall (2010) asserts the central component of material culture as the beliefs- the mental acceptance or confidence that certain things are true or real. In their definition, Hall et al. (2003) also consider both material and nonmaterial culture when describing culture.

The main components of nonmaterial culture comprises of symbols, language, values and norms.

Symbols: symbol communicates abstract concepts with visible objects. Symbols provide shared meanings to a culture and can provide loyalty, animosity, love and hate.

Language: language helps to express ideas and enables communication with others.

Values: values are ideas of right and wrong, good or bad and desirable and undesirable. Kendall asserts that values do not dictate which behaviours are appropriate or inappropriate, but provide ideas or beliefs about behaviour. Values help us to evaluate people, objects and event.

Norms: Norms have behavioural expectations that are established in the form of rules or standards of conducts. Prescriptive norms say what behaviour is appropriate or acceptable whilst proscriptive norms say what behaviour is inappropriate or unacceptable.

Norms can be further classified into informal (folkways and mores) and formal (law) according to the leading sociologist William Sumner (Sumner, 1907). Folkways are informal norms or customs that may be violated without serious consequences (Sumner, 1907). Folkways are followed through imitation and with less social pressure, but not strictly enforced by law. On the other hand, Mores are considered to be compulsory for the stability of the society (Sumner, 1907). These are informal norms that are unavoidable and are based on cultural values and deemed to be important for the well-being of the society. Formal norms such as laws are written down as legislations and enforced by formal sanctions. According to Sumner (1907) folkways and mores create 
group patterns and behaviour within a society and because of the group pressure; people in the society tend to follow them.

Many researchers assert one of the core characteristics of culture as its generational transformation of the aforementioned components of culture: knowledge, beliefs, values and norms (Kroeber and Kluckhohn, 1953, in Faulkner et al., 2006; Rapoport, 1987; Hall et al., 2003; Schein, 2004).

\subsection{Culture and livelihood}

Daskon and Binns (2010) argue that culture is closely linked with both livelihood choices and opportunities. Livelihood comprises of capabilities, assets (both material/tangible and social/intangible resources), and activities required for a means of living (Chambers and Conway, 1992). Many authors emphasise the cultural impact towards sustainable livelihood (Daskon and Binns, 2010; Adato and MeinzenDik, 2002). They argue that components of livelihood need to be expanded to include culture in addition to the components such as human capital, social capital, natural capital, financial and physical capital. When we consider the livelihood patterns of various societies, it is evident that they rely on the intangible assets such as traditional customs and knowledge, practices, beliefs, skills, and social institutions, scared sites, language, identity (Schech and Haggis, 2000; Adato and Meinzen-Dik, 2002). The research carried out by Cahn (2002) based in Pacific Island indicates that there is a strong link between culture and livelihood and emphasis livelihood must work within culture and tradition. Their study identified a number of factors that could have the impact of culture such as risk and vulnerability; access to and control of resources; choice and success of livelihood strategies; the incentives that people respond to; societal norms, gender roles and relations, traditional politics. Highlighting the importance of culture towards livelihood, Perez and Cahn (2000) asserts that sometimes unsustainable and unproductive livelihood patterns continue because of tradition and habits of communities.

By evaluating the above definitions and characteristics of culture, author summarises culture into below points: Culture...

... is a set of components (values, norms, symbols etc).

... is a way of life (that is influenced by the components).

... provides strategies for the survival.

... provides livelihood choices and opportu-

nities based on the available resources.

... influences group behaviour.

... is passed from one generation to another.

Having identified what is culture and its components, the following section discusses how the above cultural elements have affected DRR activities by evaluating some reported case studies.

\section{CULTURE AND DISASTER RISK REDUCTION}

Within the main stream literature on DRR, it is often claimed that cultural elements are neglected when planning and implementing DRR strategies (Hoffman 1999; Wisner et al., 2004; Palliyaguru et al., 2010). As asserted by Nunn et al. (2007) and Oliver-Smith and Hoffman (1999) failing to address cultural aspects could lead to increase the vulnerabilities of community towards disasters and the development of unsuccessful DRR strategies. Similarly Huntington (2000) asserts that role of cultural values and attitudes as obstacles to or facilitators to progress of DRR activities have been ignored by governments and aid agencies. Accordingly, to further evaluate the impact of culture towards DRR activities following case studies are analysed. They consider the behaviours of communities and individuals when subjecting to disastrous situations along with the underline cultural aspects of them. Further, the case studies also 
evaluate the instances where the government interventions were unsuccessful due to neglecting cultural elements of the community.

People's ideology sharpened by culture regarding what is right and wrong could create a certain mindset or beliefs for people. These cultural beliefs play a major role in DRR activities as shown in the following example. The Merapi volcano in Indonesia is one of the most active volcanoes in the world. Despite the risk from the volcano, Jevanese community lives on the slopes of the volcano due to their livelihood patterns and cultural believes. Community living near the volcano, carryout annual offerings to the volcano following their traditions. De Coster (2002, cited in Lavigne et al., 2008) reports that because of the religious beliefs, majority of community living near the area thinks that losses due to the volcanic eruption is under the control of divine forces. During the eruption of Merapi in year 2006, going against the instructions of government authorities, some communities refused to evacuate their villages until they got instructions from their "cultural leader" (Lavigne et al., 2008). This example shows that community's values judgement regarding following the orders of their cultural leader. The community's idea is such that they believe following the instructions of the cultural leader is "correct" than following scientific knowledge and instructions given by the government. Further, the community's belief regarding the relationship between god and human is strongly evident from the offerings and prayers communities do to the "gods" inherent in the hazards. Furthermore, this example shows how the behaviours of communities or groups are influenced by cultural beliefs as explained in above section (see Schein, 2004; Rapoport, 1987; Haviland, 1993). As noted by Koentjaraningrat (1985), the Javanese community living near Merapi volcano believes that the village they live in and the land they cultivate are also their ancestors. As a result of that even during a disastrous situation, people do not prefer to evacuate their village and always want to return back soon to their village- to their ancestors.

Within the definitions of culture, "knowledge" that is transferred from one generation to another was highlighted. The importance of local, indigenous knowledge towards DRR was evident during the Indian Ocean Tsunami in December 2004. It was evident that different communities and individuals reacted to the Tsunami disaster in different ways. Some communities and individuals who had indigenous knowledge regarding Tsunami were successfully survived from it. For example, the Moken community in Thailand identified the signs such as unusual behaviour of animals, birds and low tide as indications for a Tsunami from their traditional stories. Thus this community moved away from the sea towards protective areas (Arunotai, 2008). On the other hand, most of the other communities, migrants and tourists who do not have embedded historical knowledge within the mainstream regarding Tsunami did not identify Tsunami signs thus did not evacuate the danger zone. Further, some of the communities in Sri Lanka who lack such historical knowledge about the Tsunami moved towards the sea rather than moving away from the sea, when they saw the low tide created. However, author argues that lack of historical knowledge cannot be purely due to the none-existence of such knowledge. It could be also due to the none-transfer of historical knowledge and/or not accepting or ignoring historical knowledge by considering such knowledge as not valid or not according to the current state of art of the community. Nevertheless, sole reliance on indigenous knowledge for DRR activities can increase the vulnerability of people. For example, some of the traditional housing construction in Philippine island has not considered appropriate technical knowledge (Hall, 1997). Due to the readily available material from environment, traditional houses are constructed with 
bamboo trees. However, these houses do not have any measure to withstand strong winds thus fail during monsoon period.

The importance of material culture and disaster risk reduction also has a significant link. During disastrous situation, some communities did not want to evacuate their houses and other belongings indicating strong attachment towards the material that they are possessing. As noted by Lavigne et al. (2008), after the Merapi volcano eruption in year 2006, despite the danger from the volcano, some people especially the men returned to their farms and houses day and night to protect them from looters. They identified the probability of subjecting to theft higher than the threat from volcano. Further, some people returned back to their villages despite the risk from the hazard to protect their houses and belongings.

Culture and livelihood of community have a strong link as evident from literature (Daskon and Binns, 2010; Adato and Meinzen-Dik, 2002). Post-disaster recovery activities that neglected livelihood patterns of the affected community has challenged in most of the situations. For example, after the Tsunami in year 2004, Sri Lankan government impost a 100m buffer zone restricting any development within this limit. Even though the implementation of buffer zone was done to increase the safety of the community living in the coastal areas, it affected their livelihood patters and main source of income. Hence, the community continued to live and use $100 \mathrm{~m}$ buffer zone neglecting the government's restrictions. This led the government to revise the policy related to buffer zone and to develop appropriate policy that consider both livelihood patters of the community and safety (Nissanka et al., 2008). In another example, the 1992 earthquake in Flores Island in Indonesia, some communities living in Babi Island were relocated due to the possibility of subjecting those villages to Tsunami. The relocated area Nangahure, was about $200 \mathrm{~m}$ away from the shoreline. However, the relocation did not consider the social, cultural and economical conditions of the community (Boen and Jigyasu, 2005). Similar to the situation in Sri Lanka, sea was very much a part of their lives thus their livelihood - fisheries was severely affected due to the relocation. Post-disaster reconstruction activities also neglect the traditional features associated with the community's houses. For example, the earlier houses were built up on poles to prevent submerged during high tides. The fishermen used these poles to tie their boats near to their houses during high tides. However, after the relocation, houses were built up on land without considering the requirements of the community. Boen and Jigyasu (2005) report that after 8 years in 2001, most of the community has left their relocated village Nangahure, and gone back to live near the shoreline and build up their houses on poles creating a similar circumstances of 1992 earthquake condition.

\section{DISCUSSION}

The analysis of case studies in the above section linked cultural factors with DRR activities. They highlighted how culture has influenced DRR activities and vice-versa. It was evident that in some instances, culture has become a factor for the survival of the communities from disasters where as in some instances culture has acted as a barrier for effective DRR activities. Therefore, it can be argued that culture has the power of increasing or reducing vulnerability of communities towards disasters. Further, above case studies highlighted that lack of considerations on cultural aspects of the affected community can hamper effective DRR strategies thus increasing vulnerability of the affected community rather than reducing it. However, as explained in the above section (Lavigne et al., 2008; Hall, 1997) factors such as climate change, infrequent patterns of natural hazards, poverty and economic conditions of disaster vulnerable communities indicate 
that it is difficult for them to withstand the effects of disasters and survive on their own by strictly adhering to cultural believes whilst totally relying on the indigenous knowledge on disasters and DRR measures.

Literature and case studies on culture and DRR lead to three questions that need investigating.

- How to integrate positive aspects of culture towards effective DRR activities?

- How to reduce negative impact from cultural towards DRR activities?

- How to make DRR strategies and measures compatible with cultural aspects of community?

Giving due consideration to cultural aspects of communities and providing appropriate scientific knowledge to increase community resilience against natural disasters can be identified as a way forward to effectively integrate culture and DRR. However, the next question is how we can do this integration? According to the views of Schein (2004), one of the seminal authors in culture, cultural beliefs can take two forms: espouse and actual. People like to promote or possess espoused cultural beliefs where as actual beliefs are manifest through one's unconscious behaviour. Understanding culture by only studying the surface level manifestation can therefore be not successful as people may claim one but the actual underlying belief can be different. Proper engagement with culture is therefore, a vital part if we are to utilise culture towards effective DRR activities and vice-versa. Accordingly, community based DRR activities are considered as a better way of integrating cultural aspects for effective DRR activities (Mercer, 2009). Community based DRR activities are a form of participant empowerment and a mechanism that transfer ideas from community to the authorities who take decisions at the top level of the governance system. Further, community based DRR activities provide opportunities for the affected community to provide their contribution towards the development of DRR strategies and measures thus increasing community's commitment and belongingness for the disaster management activities that they are involved in. For instance the study carried out by Ratnayake and Rameezdeen (2008) revealed that the owner driven housing reconstruction activities after the Tsunami disaster was much successful than the donor driven housing reconstruction. The owner driven housing reconstruction were led by the community that were affected by the Tsunami with external financial support and technical assistance where as donor driven housing programmes were completely handled by donor agencies. Above case studies indicated that in some instances, communities going against the government's disaster mitigations strategies and evacuation efforts by strictly following the traditional cultural beliefs of the society (see Lavigne et al., 2008). However, community based DRR activities can be used as a mechanism to provide awareness to the community about the risks that they could encounter from such cultural beliefs.

\section{CONCLUSION}

The study evaluates the influence of culture towards DRR activities. Definitions of culture indicated that culture is important to the individuals as well as to the society. As individuals, people rely on culture because; it provides information for them to survive in the world. Survival of the society also depends on the culture as without systems, rules and laws that protect the rights of the society, it will not survive. Culture provides certain identity to a community based on the common language, values and norms that they have, and the symbols they are used to. Due to the generational transformation of cultural components such as knowledge, beliefs, values and norms, society's values are preserved for the future. This also helps to further strengthen the sustainability 
and identity of the society/community. Due to the close link between culture and group, culture can be an enormously stabilising aspect for a society as well as could lead to conflicts and violence when people within the group act differently than the set cultural values of the group. Culture is strongly linked with livelihood patterns of the communities thus when the cultural factors are aligned with the livelihood patterns, communities can be more resilience towards economic, social and environmental challenges. This is due to the fact that a community's culture is closely linked with resource availability in the society, traditional knowledge that is being transferred from generations that provide guidance to survive.

The strong link between culture and disaster risk-averseness was evident from the paper. The risk perception regarding disasters and the impact these disasters can bring towards community and individuals can be influenced by the cultural aspects such as beliefs, traditional knowledge, values, behaviour of the community/group that they are belonging to, livelihood patterns etc. It was also identified that culture can act as a both positive and negative aspect for DRR. Therefore, the paper emphasis the importance of sustaining and integrating with culture that reduces risk, and also engaging with culture that increases the vulnerability of communities from disasters. It is important to make the DRR strategies compatible with cultural aspects of the community in further strengthening community's coping capacity towards disasters. Further, the integration of local knowledge with appropriate scientific knowledge in an effective way to make the disaster affected communities resilience against natural disasters and their impacts also emphasised.

\section{REFERENCES}

Adato, M. and Meinzen-Dik, R. (2002) Assessing the impact of agricultural research on poverty using the sustainable livelihood framework, International food policy institute, USA.

Arunotai, N. (2008) Saved by an old legend and a keen observation: the case of Moken sea nomads in Thailand, In: Shaw, R., Uy, N. and Baumwoll, J. (eds.), Indigenous knowledge for disaster risk reduction: good practices and lessons learnt from the Asia-Pacific region. UN ISDR Asia and Pacific, Bangkok, pp. 73-78.

Baligh, H. H. (1994) Components of culture: nature, interconnections and relevance to the decisions on the organisational structure, Management Science, 40(1), pp. 14-27.

doi:10.1287/mnsc.40.1.14

Boen, T. and Jigyasu, R. (2005) Cultural considerations for post-disaster reconstruction: posttsunami challenges. [Online] Asian Disaster Preparedness Center (ADPC). Available at: http://www.adpc.net/irc06/2005/4-6/TBindo1. pdf [accessed July 2010]

Cahn, M. (2002) Sustainable livelihood approach: concept and practice. [Online] The Aotearoa New Zealand International Development Studies Network. Available at: http://forum.devnet. org.nz/conf2002/papers/Cahn_Miranda.pdf [accessed June 2010]

Chambers, R. and Conway, G. R. (1992) Sustainable rural livelihoods: practical concepts for the $21^{\text {st }}$ century, IDS discussion paper no. 296, IDS, Brighton.

Daskon, C. and Binns, T. (2010) Culture, tradition and sustainable rural livelihoods: exploring the culture-development interface in Kandy, Sri Lanka, Community Development Journal, 45(4), pp. 494-517. doi:10.1093/cdj/bsp019

EM-DAT (2009) The International Disaster Database. [Online] Center for Research on the Epidemiology of Disasters (CRED). Available online: http://www.emdat.be/explanatory-notes [accessed June 2010]

Faulkner, S., Baldwin, J. and Linsley, S. (2006) Layers of meaning: an analysis of definition of culture. In: Baldwin, J. R., Faulkner, S. L., Hecht, M. L. and Lindsley, S. L. (eds.), Redefining Culture: Perspective Across the Disciplines, Lawrence Erlbaum Associates, Inc., New Jersey, pp. 27-52.

Hall, J. R., Neitz, M. J. and Battani, M. (2003) Sociology on culture. New York: Routledge.

Hall, N. (1997) Incorporating local level mitigation strategies into national and international 
disaster responses, In: Scobie, J. (ed.), Mitigating the Millennium, Intermediate Technology Development Group, Rugby, pp. 35-45.

Haigh, R. and Amaratunga, D. (2010) An integrative review of the built environment discipline's role in the development of society's resilience to disasters, International Journal of Disaster Resilience in the Built Environment, 1(1), pp. 11-24. doi:10.1108/17595901011026454

Haviland, W. A. (1993) Cultural anthropology. Orlando, Florida.

Hoffman, S. M. (1999) Anthropology and the angry earth: an overview. In: Oliver-Smith, A. and Hoffmann, S. M. (eds.), The angry earth: disasters in anthropological perspective, New York: Routledge, pp. 1-16.

Huntington, S. P. (2000) Foreword - cultures count. In: Harrison, L. E. and Huntington, S. P. (eds.), Culture matters: how values shape human progress, New York: Basic Books.

Kendall, D. (2010) Sociology in our times, $8^{\text {th }}$ Edition. Wadsworth Publishing, CENGAGE Learning, USA.

Koentjaraningrat, A. (1985) Javanese culture. Oxford University Press, Singapore.

Kroeber, A. L. and Kluckhohn, C. (1953) Culture, a critical view of concepts and definitions. Cambridge: Harvard University Press.

Lavigne, F., de Coster, B., Juvin, N., Flohic, F., Gaillard, J.-C., Texier, P., Morin, J. and Sartohadi, J. (2008) People's behaviour in the face of volcanic hazards: perspectives from Javanese communities, Indonesia, Journal of Volcanology and Geothermal Research, 172(3-4), pp. 273-287.

doi:10.1016/j.jvolgeores.2007.12.013

McEntire, D., Crocker, C. G. and Peters, E. (2010) Addressing vulnerability through an integrated approach, International Journal of Disaster Resilience in the Built Environment, 1(1), pp. 50-64. doi:10.1108/17595901011026472

Mercer, J. (2009) Cultural perceptions of hazard and risk, keynote, Disaster risk reduction for natural hazards: putting research into practice, University College London, 4-6 ${ }^{\text {th }}$ November 2009.

Nanda, S. and Warms, R. L. (2007) Cultural anthropology. Wadsworth/Thomson Learning, Belmont, CA.
Nissanka, N. M. N. W. K., Karunasena, G. and Rameezdeen, R. (2008) Study of factors affecting post disaster housing reconstruction. In: Keraminiyage, K., Jayasena, S., Amaratunga, D. and Haigh. R. (eds.), CIB W89: International Conference in Building Education and Research on Post Disaster Recovery Challenges in Sri Lanka, The University of Salford, UK. Heritance Kandalama, 11th-15th February 2008, Sri Lanka.

Nunn, N. P. D., Hunter-Anderson, R., Carson, M. T., Thomas, F., Ulm, S. and Rowland, M. J. (2007) Times of plenty, times of less: last-millennium societal disruption in the Pacific Basin, Human Ecology, 35(4), pp. 385-401. doi:10.1007/s10745-006-9090-5

Ogburn, W. F. (1966) Social change: with respect to cultural and original nature. Oxford England: Delta Books.

Oliver-Smith, A. S. (1996) Anthropological research on hazards and disasters, Annual Review of Anthropology, 25, pp. 303-328. doi:10.1146/annurev.anthro.25.1.303

Oliver-Smith, A. S. and Hoffman, S. M. (1999) The angry earth. New York: Routledge.

Palliyaguru, R., Amaratunga, D. and Haigh, R. (2010) Integration of "disaster risk reduction" into infrastructure reconstruction sector: policy vs practise gaps", International Journal of Disaster Resilience in the Built Environment, 1(3), pp. 277-296. doi:10.1108/17595901011080878

Perez, I. N. and Cahn, M. (2000) Water and livelihoods: a participatory analysis of a Mexican rural community, Research report 00/01 Division of applied management and computing, Lincoln University, NZ.

Rapoport, A. (1987) On the cultural responsiveness of Architecture, Journal of Architectural Education, 41(1), pp. 10-15. doi:10.2307/1424903

Ratnayake, R. M. G. D. and Rameezdeen, R. (2008) Post disaster housing reconstruction: comparative study of donor driven vs. owner driven approach. In: Keraminiyage, K., Jayasena, S., Amaratunga, D. and Haigh. R. (eds.), CIB W89: International Conference in Building Education and Research on Post Disaster Recovery Challenges in Sri Lanka, The University of Salford, UK. Heritance Kandalama, 11th-15th February 2008, Sri Lanka. 
Schaefer, R. T. (2009) Sociology: a brief introduction, ${ }^{\text {th }}$ Edition. New York: McGraw-Hill.

Schech, S. and Haggis, J. (2000) Culture and development: a critical introduction. Oxford: Blackwell.

Schein, E. H. (2004) Organizational culture and leadership. San Francisco: Jossey-Bass.

Sumner, W. G. (1907) Folkways: a study of the sociological importance of usages, manners, customs, mores, and morals. Boston: Ginn and Company.

Swidler, A. (1986) Culture in action, American Sociological Review, 51(2), pp. 273-286. doi:10.2307/2095521

Taylor, W. (1924) Primitive culture, $7^{\text {th }}$ Edition. New York: Brentano's.
Throsby, D. (2001) Economics and culture. Cambridge: Cambridge University Press.

UN/ISDR (2009) 2009 UN/ISDR terminology on disaster risk reduction. Geneva: United $\mathrm{Na}$ tions International Strategy for Disaster Reduction (UN/ISDR).

UNESCO (2003) Convention for the safeguarding of the intangible cultural heritage. [Online] UNESCO. Available at: http://www.unesco.org/ culture/ich/index.php [accessed June 2010]

Williams, R. (1961) The long revolution. London: Chatto and Windus.

Wisner, B., Blaikie, P., Cannon, T. and Davis, I. (2004) At risk: natural hazards, people's vulnerability and disasters, $2^{\text {nd }}$ Edition. London: Routledge.

\section{SANTRAUKA}

\section{KULTŪROS POVEIKIS MAŽINANT NELAIMIŲ KELIAMĄ RIZIKĄ}

\section{Udayangani KULATUNGA}

Pasaulyje gerokai padaugèjo stichinių nelaimiu, taigi ju keliama rizika jaudina visa pasauli. Dèl tokių nelaimių daug nuostolių ir žalos patiria žmonès, ekonomika ir visuomenė. Nepaisant nuostolių ir žalos, kurią atneša nelaimès, kai kurie individai ir bendruomenès stichinėms nelaimèms neteikè daug reikšmės. Iš nelaimės kylančios rizikos suvokimas priklauso ne tik nuo pavojaus, kuri tokia nelaimè gali sukelti, bet ir nuo bendruomenių bei individų elgsenos, kurią lemia jų kultūra. Atsižvelgiant i i ši konteksta, darbe nagrinëjamas ryšys tarp kultūros ir nelaimių keliamos rizikos mažinimo. Siekiant i̇vertinti kultūrą ir jos komponentus, išanalizuoti keli su nelaimiu rizika susiję atvejai, tyrime plačiai apžvelgiama literatūra. Iš tyrimo paaiškejjo, kad kai kuriais atvejais kultūra per nelaimes lemė bendruomeniu išlikima, o kitais atvejais trukdè efektyviam nelaimiu keliamos rizikos mažinimui. Tyrime bendruomenių vykdoma nelaimiu keliamos rizikos mažinimo veikla siūloma kaip mechanizmas, leidžiantis integruojant kultūrą efektyviai valdyti nelaimiu keliamą riziką. 